\title{
A Statistical Study of Ultra-Long Waves
}

\author{
By Y. Arai \\ Meteorological Research Institute, Tokyo, Japan \\ (Manuscript received 2 May 1970, in revised form 18 September 1970)
}

\begin{abstract}
Zonal harmonic analyses were applied to 5-day mean heights, 25-day mean heights, departures from 25-day mean heights, depatures from the normal and tendency fields on the 500-mb level. It was found that the first and second harmonics for transient waves at $70^{\circ}$ and $60^{\circ} \mathrm{N}$ generally move westward. The mean westward phase velocities are about a quarter of the wave-length per five days, i. e., about $20^{\circ}$ and $10^{\circ}$ longitude per day for the first and second harmonics respectively. The westward movement was not pronounced at lower latitudes mainly due to the small amplitude of transient waves.

The frequency distributions of phase velocities of transient waves for the third harmonic are nearly uniform and the third harmonic does not reveal mean westward or eastward movements. The fourth harmonic moves eastward with a mean phase velocity of about $6^{\circ}$ longitude per day at $70^{\circ}$ and $60^{\circ} \mathrm{N}$. On the contrary, the fourth harmonic at low latitudes has a tendency to move westward in summer.

The mean phase velocities of the first two harmonics are nearly the same for each season, and the amplitudes of transient waves are large in winter and small in summer.

As the present study is based on the data for 20 years or more, namely more than 1460 cases for each harmonic, the results obtained are statistically significant. Several examples of travelling waves were presented for the first four harmonics at $60^{\circ} \mathrm{N}$.
\end{abstract}

\section{Introduction}

Zonal harmonic analyses have been employed by many researchers in the study of long and ultra-long waves. Kubota and Iida (1954), Eliasen (1958) and Arai (1965) discussed the behavior of planetary waves mainly on daily $500-\mathrm{mb}$ charts. Anderssen (1965) carried out an analysis of long waves in the southern hemisphere comparing with results obtained in the northern hemisphere. Using 5-day mean 500-mb maps, Haney (1961) stated that the first harmonic at $70^{\circ} \mathrm{N}$ moved generally westward for the 6-month period.

Recenty travelling planetary-scale waves were investigated using spherical harmonics by Deland (1964, 1965), Deland and Johnson (1968) and Eliasen and Machenhauer (1965). They showed that the largest components move generally westward at speeds variously estimated at $40^{\circ}$ to $70^{\circ}$ longitude per day for a relatively short time period. It is desirable to study the behavior of ultra-long waves for a certain long time period, since the behavior of ultra-long waves differs markedly from year to year as shown by Arai (1970). The 500-mb heights employed in this study may be sufficient in this respect.

Generally speaking, the ultra long waves oscillate around their mean location, if we disregard the seasonal variation that was discussed by Arai (1970). The separation of waves into standing and transient ones is not only convenient but also essential because we can thus study the movement of ultra-long waves precisely. Deland and Eliasen have also suggested that the fluctuations in position and amplitude of planetary-scale waves are due to the simultaneous presence of a stationary and a travelling component.

The standing waves in the present study mean the waves on 25 -day mean 500 -mb fields. The waves on 5-day mean $500-\mathrm{mb}$ fields, departures from the 25-day mean, on the other hand, are named "transient waves." Thus the waves on 5-day mean fields are composed of standing and transient waves.

The basic data employed are 5-day mean 500$\mathrm{mb}$ heights for more than 20 years since April 1947. Therefore, variations with time-scales less than 5 days and longer than about one month 
or more are eliminated in the variations of transient waves. The purpose of this study is to investigate the existence and charracteristics of travelling ultra-long waves in the middle troposphere.

\section{Data and method employed}

The 5-day mean 500-mb heights are arranged as follows:

(a) 5-day mean heights,

(b) 25-day mean heights,

(c) departures from 25-day mean heights: (a)(b),

(d) anomalies of 5-day mean heights,

(e) time-change, 5 days tendency, of 5-day mean heights.

The waves on the fields of (a), (b), (c), (d) and (e) are styled 5-day mean, standing, transient, anomaly and time-change waves respectively for convenience' sake in the present study, since there are no generally accepted names of the waves on these fields.

One year is divided into 73 pentads, assigning for instance, the 1st pentad to the 5-day period from 1 to 5 January and the last (73rd) to that from 27 to 31 December. The five-pentad moving average of 20-year means, i. e., the mean of 100 values, is defined as the "normal" of 5-day mean $500-\mathrm{mb}$ heights on each pentad. The same normal is also applied to the normal of the 25-day mean heights. Therefore, the normals of 5-day and 25day mean heights are the same for each pentad.

By the definition we get

(c) $=(a)-(b)$

(d) $=($ a) - the normal of (a),

and $(\mathrm{c})=(\mathrm{d})$ - anomaly of $(\mathrm{b})$.

The second term on the right hand side varies generally more gradually than the first term (d). Therefore, even when the displacement of transient waves for (c) is observed, the anomaly waves do not necessarily move. To see this relationship, amplitudes and phase angles of aomaly waves are calculated. It may be also valuable to study the diaplacement of anomaly waves because positive anomaly centers have been traced in many synoptic analyses. It is convenient to see the movement of transient waves on 5-day mean $500-\mathrm{mb}$ maps, since we are more familiar (a) and (d) than (c).

There are a few ways to separate standing and transient waves from 5-day mean waves. One of these ways is to use the time-change of 5-day mean $500-\mathrm{mb}$ height (e). The same procedure, 24 hours tendency, has been employed by Eliasen and Machenhauer (1965) and Hirota (1968), in order to bring out the travelling planetary waves more clearly.

Zonal harmonic analyses are applied to the waves on the fiedls for (a), (b), (c), (d) and (e) for each degree of latitude from $70^{\circ}$ to $30^{\circ} \mathrm{N}$. The $500-\mathrm{mb}$ heights are obtained for each $10^{\circ}$ longitude and latitude from $60^{\circ}$ to $30^{\circ} \mathrm{N}$ and for $20^{\circ}$ longitude at $70^{\circ} \mathrm{N}$. Amplitudes are in gpm but expressed as $\mathrm{m}$ for simplicity. Phase angles are counted as zero at Greenwich and increase toward the east through $360 \mathrm{deg}$. It is noticed that phase angles are in deg. but not deg. longitude.

\section{Phase velocities of the first and second harmonics}

The frequency distributions of phase velocities of the first harmonic are presented in Figs. 1a, $1 \mathrm{~b}$ and $1 \mathrm{c}$ for 5-day mean, anomaly and transient waves respectively. The frequency distribution at $50^{\circ} \mathrm{N}$ given in Fig. 1a is considerably sharp and the frequency of westward movement (negative phase velocity) is nearlly the same as that of eastward movement. This shows that 5-day mean waves at $50^{\circ} \mathrm{N}$ are stationary on the average.

The frequency of westward displacement is larger and the maximum frequency is smaller at $60^{\circ} \mathrm{N}$ than at $50^{\circ} \mathrm{N}$. These characteristics are more pronounced at $70^{\circ} \mathrm{N}$, suggesting the existence of westward travelling waves at high latitudes. The maximum frequency at $70^{\circ} \mathrm{N}$ is the smallest of all, showing a large variability of 5-day mean weves.

The frequency distributions of phase velocities for anomaly waves in Fig. $1 \mathrm{~b}$ show that the westward displacements are more clear for each latitude than those of 5-day mean waves. However, the maximum frequencies are considerably small compared with those of 5-day mean waves at $60^{\circ}$ and $50^{\circ} \mathrm{N}$. The frequency distributions for transient waves in Fig. 1c show that the westward movement is the most pronounced of all for the first harmonic. The mean westward phase velocity at $70^{\circ}$ and $60^{\circ} \mathrm{N}$ is about $90^{\circ}$ per 5 days. This westward speed is equal to a quarter of the wave-length per 5 days, or about $20^{\circ}$ longitude per day. The distributions at $50^{\circ}, 40^{\circ}$ and $30^{\circ} \mathrm{N}$ are not so sharp. We can see that the westward movement of transient waves is more pronounced at higher than at lower latitudes.

Fig. 2 is the frequency distributions of phase 


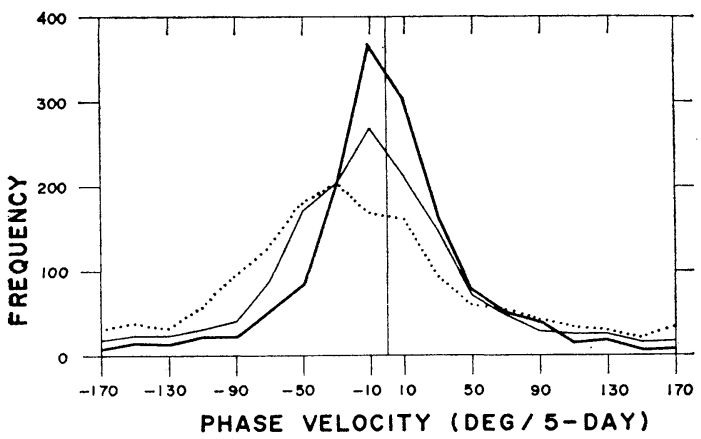

Fig. 1a. Frequency distributions of phase velocities for 5-day mean waves, the first harmonic, at $70^{\circ} \mathrm{N}$ (dotted line), $60^{\circ} \mathrm{N}$ (thin full line) and $50^{\circ} \mathrm{N}$ (heavy full line). Phase velocities are in deg. per 5 days and equal to longitudinal speeds in deg. longitude per 5 days.

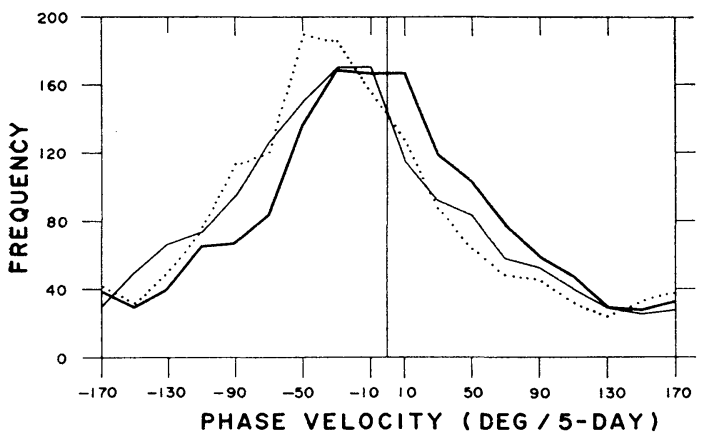

Fig. 1b. The same as Fig. 1a but for anomaly waves.

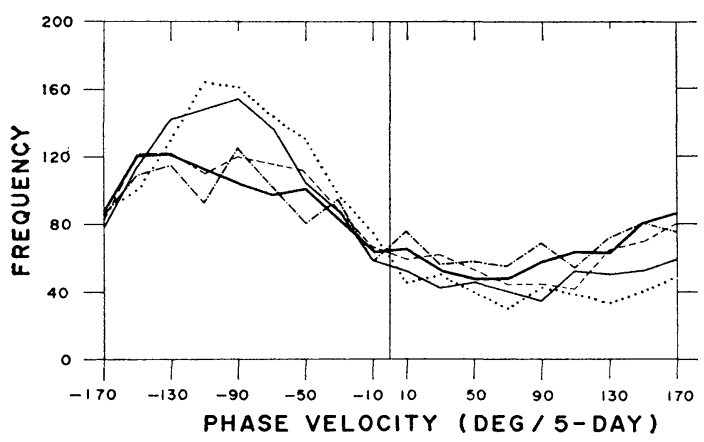

Fig. 1c. Frequency distributions of phase velocities for transient waves, the first harmonic, at $70^{\circ} \mathrm{N}$ (dotted line), $60^{\circ} \mathrm{N}$ (thin full line), $50^{\circ} \mathrm{N}$ (heavy full line), $40^{\circ} \mathrm{N}$ (dotted broken line) and $30^{\circ} \mathrm{N}$ (broken line).

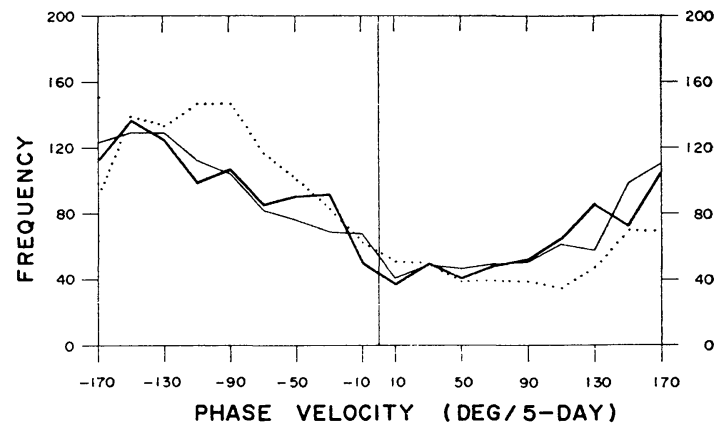

Fig. 2. Frequency distributions of phase velocities for time-change waves, the first harmonic, at $70^{\circ} \mathrm{N}$ (dotted line), $50^{\circ} \mathrm{N}$ (heavy full line) and $30^{\circ} \mathrm{N}$ (thin full line).

velocities of the first harmonic for time-change waves at $70^{\circ}, 50^{\circ}$ and $30^{\circ} \mathrm{N}$. Fig. 2 gives the same feature as Fig. 1c but the mean westward phase velocities are a little larger than thoes of transient waves.

The second harmonic has generally the same characteristics as the first. This is seen in Figs. $3 a, 3 b$ and $3 c$. Figs. $3 a, 3 b$ and $3 c$ are the frequency distributions of the second harmonic for 5-day mean, anomaly and transient waves respectively. It is noted again that the maximum frequency caused by standing waves in Fig. 3a disappears in Fig. $3 c$ and that caused by westward travelling waves appears at $60^{\circ} \mathrm{N}$ in Fig. 3c. The maximum frequency for transient waves at $60^{\circ} \mathrm{N}$ is about $70 \%$ of that for 5-day mean waves showing the large variability of transient waves. The mean westward phase velocity at $60^{\circ} \mathrm{N}$ is about $90^{\circ}$ per 5 days. This westward speed is equal to a quarter of the wave-length per 5 days or about $10^{\circ}$ longitude per day. The distributions at $40^{\circ}$ and $30^{\circ} \mathrm{N}$ is considerably flat, and the westward travelling waves are observed mostly at $60^{\circ} \mathrm{N}$. The result mentioned above means that the mean westward speeds of transient waves for the first and second harmonics depend on the wave-length.

The phase angles and phase velocities are generally unreliable when the amplitudes are very small. The jumps or discontinuous changes of phase angles occur largely in such cases. Then it is necessary to illustrate the frequency distributions for two classes: cases with large amplitudes and those small amplitudes. The critical values of amplitude, about $20 \mathrm{~m}$, at $70^{\circ}, 60^{\circ}$ and $50^{\circ} \mathrm{N}$ are 


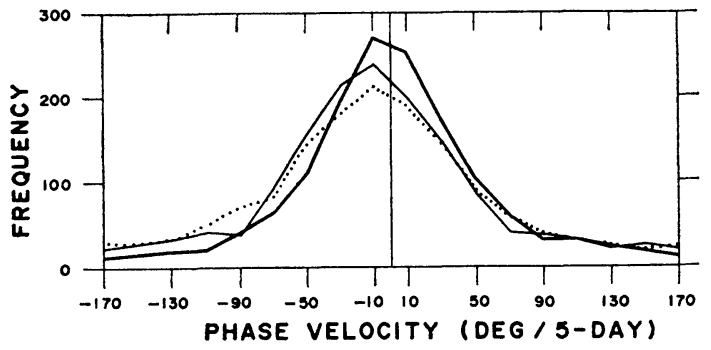

Fig. 3a Frequency distributions of phase veloc ities for 5-day mean waves, the second harmonic, at $70^{\circ} \mathrm{N}$ (dotted line), $60^{\circ} \mathrm{N}$ (thin full line) and $50^{\circ} \mathrm{N}$ (heavy full line). Phase velocities are in deg. per 5 days and longitdinal speed in deg. longitude per 5 days is equal to (phase velocity) $/ 2$.

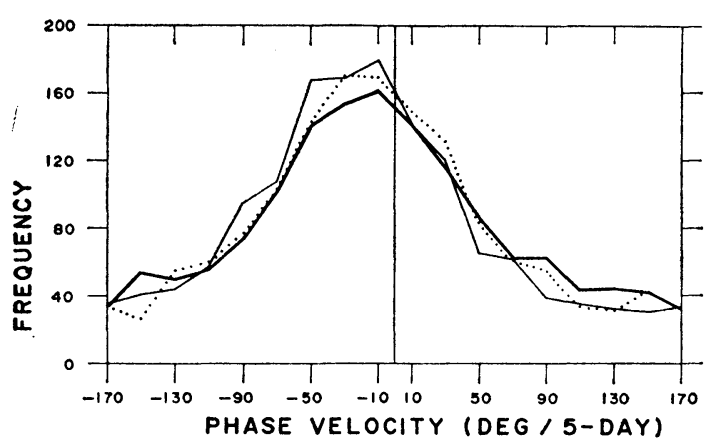

Fig. 3b. The same as Fig. 3a but for anomaly wave.

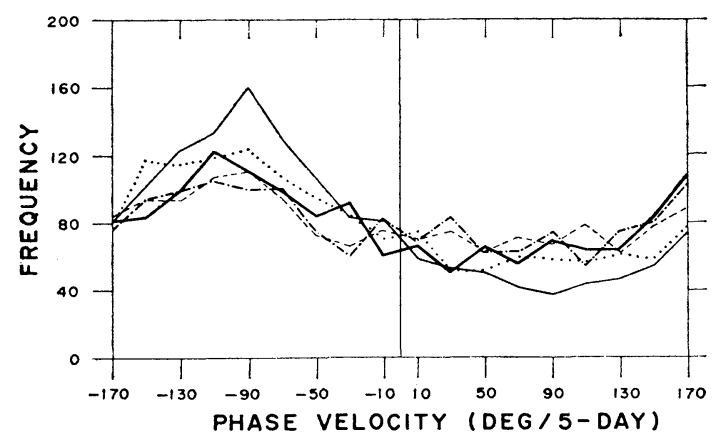

Fig. 3c. Frequency distribuions of phase velocities for transient waves, the second harmonic, at $70^{\circ} \mathrm{N}$ (dotted line), $60^{\circ} \mathrm{N}$ (thin full line), $50^{\circ} \mathrm{N}$ (heavy full line). $40^{\circ} \mathrm{N}$ (dotted broken line) and $30^{\circ} \mathrm{N}$ (broken line).
Table 1. Critical values of the amplitude of the first and second harmonics at $70^{\circ}, 60^{\circ}$ and $50^{\circ} \mathrm{N}$, and number of cases for the two classes.

\begin{tabular}{|c|c|c|c|c|c|c|c|}
\hline \multicolumn{2}{|c|}{ Latitude } & \multicolumn{2}{|c|}{$70^{\circ} \mathrm{N}$} & \multicolumn{2}{|c|}{$60^{\circ} \mathrm{N}$} & \multicolumn{2}{|c|}{$50^{\circ} \mathrm{N}$} \\
\hline \multicolumn{2}{|c|}{ Critical value } & \multicolumn{2}{|c|}{$27 \mathrm{~m}$} & \multicolumn{2}{|c|}{$22 \mathrm{~m}$} & \multicolumn{2}{|c|}{$17 \mathrm{~m}$} \\
\hline \multicolumn{2}{|c|}{ Wave-number } & 1 & 2 & 1 & 2 & 1 & 2 \\
\hline $\begin{array}{l}\text { Number } \\
\text { of cases }\end{array}$ & $\begin{array}{c}\text { amp. } \geqq \text { crit. value } \\
\text { amp. }<\text { crit. value } \\
\text { total }\end{array}$ & $\begin{array}{r}1042 \\
418 \\
1460\end{array}$ & $\begin{array}{r}920 \\
540 \\
14601\end{array}$ & $\begin{array}{r}979 \\
481 \\
1460\end{array}$ & $\begin{array}{r}984 \\
476 \\
1460\end{array}$ & $\begin{array}{r}936 \\
524 \\
1460\end{array}$ & $\begin{array}{r}990 \\
470 \\
1460\end{array}$ \\
\hline
\end{tabular}

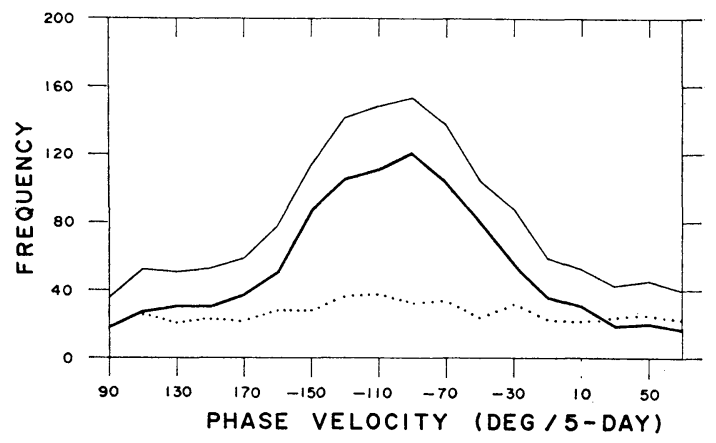

Fig. 4a. Frequency distributions of phase velocities of transient waves for the first harmonic at $60^{\circ} \mathrm{N}$, Thin full line: all cases, heavy full line: cases with large amplitude and dotted line: cases with small amplitude.

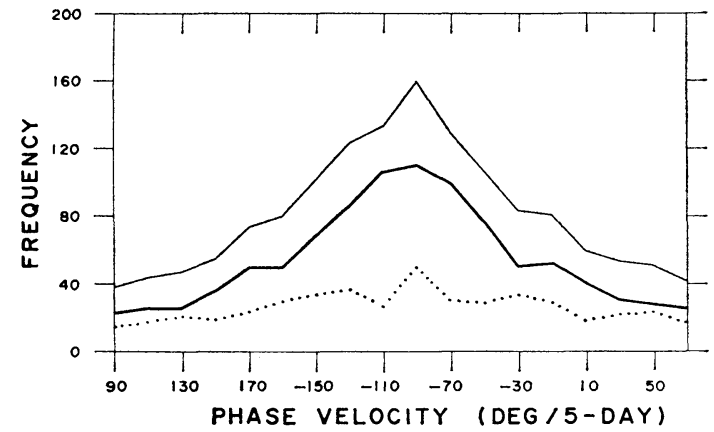

Fig. $4 \mathrm{~b}$ The same as Fig. $4 \mathrm{a}$ but for the second harmonic. 
Table 2. Number of cases with westward phase velocities, ratio to all cases of 1460 in 20 years, in per cent for various waves of the first and second harmonics at $70^{\circ}, 60^{\circ}$ and $50^{\circ} \mathrm{N}$.

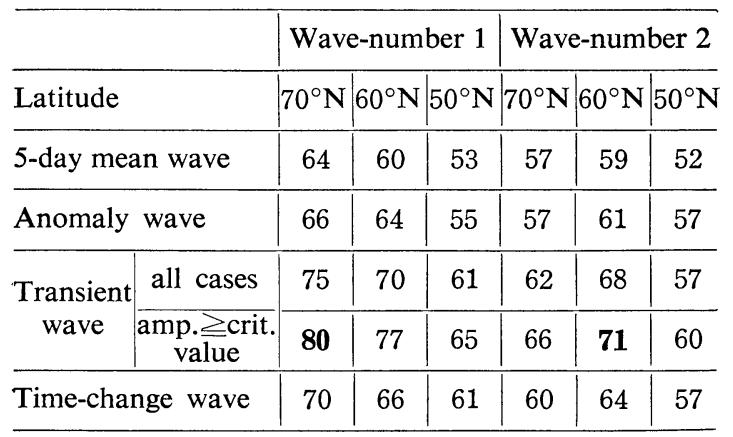

chosen to distinguish the two classes based on the result given by Arai (1970). These values are given in Table 1 for first two harmonics as well as the number of cases for the two classes.

The frequency distributions of phase velocities for each class at $60^{\circ} \mathrm{N}$ are indicated in Figs. 4a and $4 \mathrm{~b}$ for the first and second harmonics respectively. Fig. 4a shows that the distribution is mostly uniform when the amplitudes are small, and that, inversely, it has a peak in cases with large amplitudes. This confirms again the significance of the mean westward movement of transient waves. The same behavior can be seen in Fig. $4 \mathrm{~b}$ for the second harmonic, but it is less pronounced than the first harmonic.

The number of cases with westward phase velocities, expressed in a ratio to the all 1460 cases in 20 years, is presented in percentage for various waves of the first and second harmonics at $70^{\circ}$, $60^{\circ}$ and $50^{\circ} \mathrm{N}$ in Table 2. Selecting the cases with amplitudes larger than the critical value given in Table 1, the same ratio is presented also in Table 2 for transient waves only.

Table 2 revea ls that the ratio, the frequency of westward movement, is larger than $50 \%$ and largest for transient waves, i. e., $80 \%$ for the first harmonic at $70^{\circ} \mathrm{N}$ and $71 \%$ for the second harmonic at $60^{\circ} \mathrm{N}$. This is significant and shows the mean westward movement of transient waves at high latitudes.

If we select the cases with amplitudes larger than $20 \mathrm{~m}$ for the first harmonic at $30^{\circ} \mathrm{N}, 101$ cases in all, then the frequency of westward movement of transient waves becomes $79 \%$. This shows that the flat frequency distributions of phase velocities at lower latitudes are mainly due to the smallness of amplitude. It is noted further that the time-change waves, the waves on the tendency fields of 5-day mea 500-mb heights, have the same characteristic as the transient waves, though the ratio is not very large.

\section{Phase velocities of the third and fourth harmonics}

The frequency distributions of phase velocities of the third harmonic are presented in Figs. 5a, $5 \mathrm{~b}$ and $5 \mathrm{c}$ for 5-day mean, anomaly and transient waves respectively. It is observed in Figs. 5a and $5 \mathrm{~b}$ that the 5-day mean and anomaly waves are generally stationary. In contrast to the first and second harmonics, the distributions for transient waves, Fig. 5c, are nearly uniform. Furthermore, as the amplitudes of the third harmonic at $60^{\circ} \mathrm{N}$ are not small (see Fig. 7), the third harmonic does not show the mean westward or eastward displacements.

Figs. $6 a, 6 b$ and $6 c$ are the frequency distributions of phase velocities of the fourth harmonic for various waves. The distributions for 5-day mean waves, Fig. 6a, are generally similar to those for the second and third harmonics. Comparing the figure with Figs. 1a, 3a and 5a, we can see that the maximum frequencies become small with the increasing wave-number. There exists a tendency to eastward movement at $70^{\circ}$ and $60^{\circ} \mathrm{N}$ as can be seen in Fig. 6b for anomaly waves. This is more pronounced in Fig. 6c, which shows the frequency distributions for transient waves. The mean eastward phase velocities at $70^{\circ}$ and $60^{\circ} \mathrm{N}$ are about $120^{\circ} / 5$-day. This speed is equal to the longitudinal speed of $6^{\circ}$ longitude/day. On the other hand, the frequency distributions at $40^{\circ}$ and $30^{\circ} \mathrm{N}$ show that the transient waves have a tendency to move westward on the average. This is associated with the summer circulation, since the distribution in summer at $40^{\circ} \mathrm{N}$ is nearly the same as that given in Figs. 6c, whereas it is mostly uniform in winter.

It is considered from the foregoring results that the third harmonic may be a critical harmonic, because the statistical aspects of this harmonic are different from those of the first two and fourth harmonics.

\section{Seasonal variation of transient waves}

The normal amplitudes of transient waves are given in Fig. 7 for the first four harmonics at $60^{\circ} \mathrm{N}$, where the definition of the normal is the same as that of 5-day mean $500-\mathrm{mb}$ heights. Fig. 


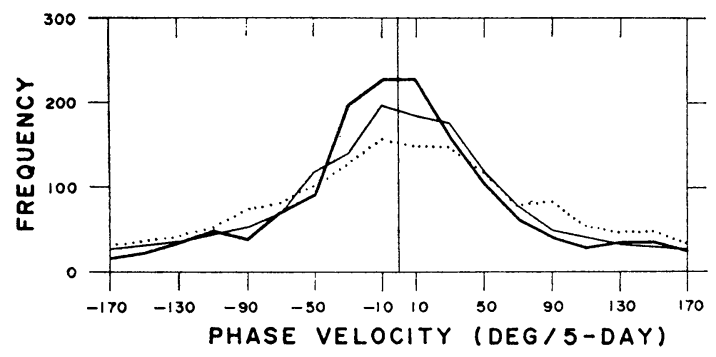

Fig. 5a. Frequency distributions of phase veloc ities for 5-day mean waves, the third harmonic, at $70^{\circ} \mathrm{N}$ (dotted line), $60^{\circ} \mathrm{N}$ (thin full line) and $50^{\circ} \mathrm{N}$ (heavy full line). Phase velocities are in deg. per 5 days and longitudinal speed in deg. longitude per 5 days is equal to (phase velocity) $/ 3$.

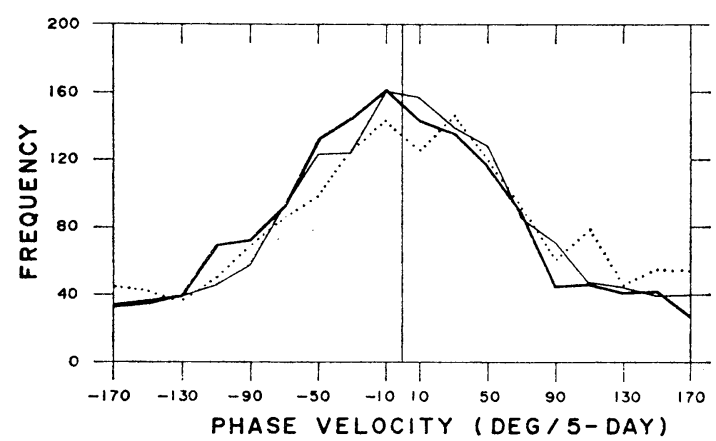

Fig. 5b. The same as Fig. 5a but for anomaly waves.

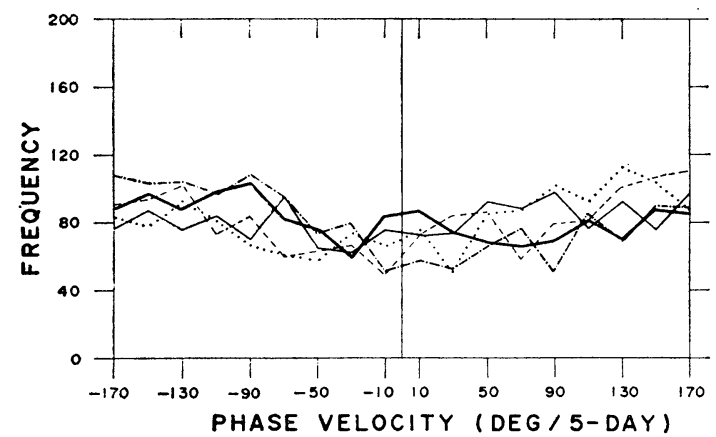

Fig. 5c Frequency distributions of phase velocities for transient waves, the third harmonic at $70^{\circ} \mathrm{N}$ (dotted line), $60^{\circ} \mathrm{N}$ (thin full line), $50^{\circ} \mathrm{N}$ (heavy full line), $40^{\circ} \mathrm{N}$ (dotted broken line) and $30^{\circ} \mathrm{N}$ (broken line).

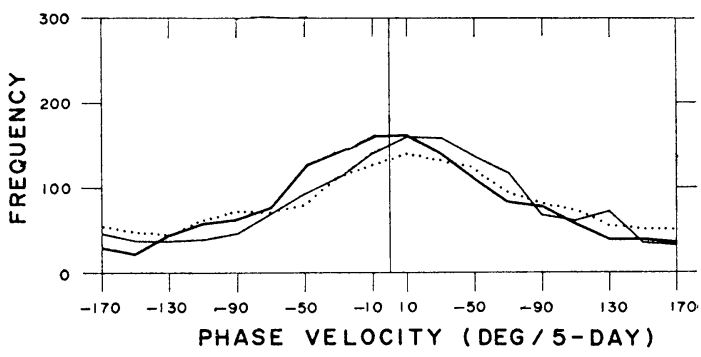

Fig. 6a. Frequency distributions of phase velocities for 5-day mean waves, the fourth harmonic, at $70^{\circ} \mathrm{N}$ (dotted line), $60^{\circ} \mathrm{N}$ (thin full line) and $50^{\circ} \mathrm{N}$ (heavy full line). Phase velocities are in deg. per 5 days and longitudinal speed is equal to (phase velocity) $/ 4$.

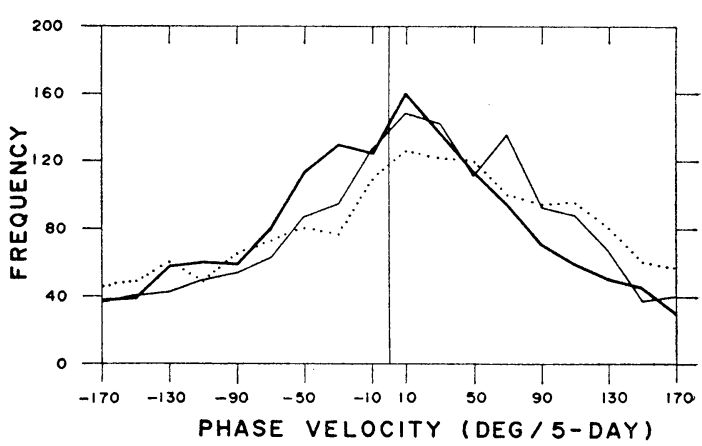

Fig. 6b. The same as Fig. 6a but for anomaly waves.

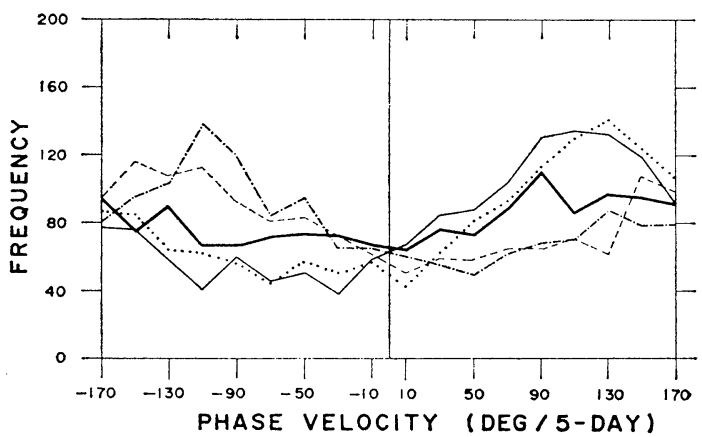

Fig. 6c. Frequency distributions of phase velocities for transient waves, the fourth harmonic, at $70^{\circ} \mathrm{N}$ (dotted line), $60^{\circ} \mathrm{N}$ (thin full line), $50^{\circ} \mathrm{N}$ (heavy full line), $40^{\circ} \mathrm{N}$ (dotted broken line) and $30^{\circ} \mathrm{N}$ (broken line). 


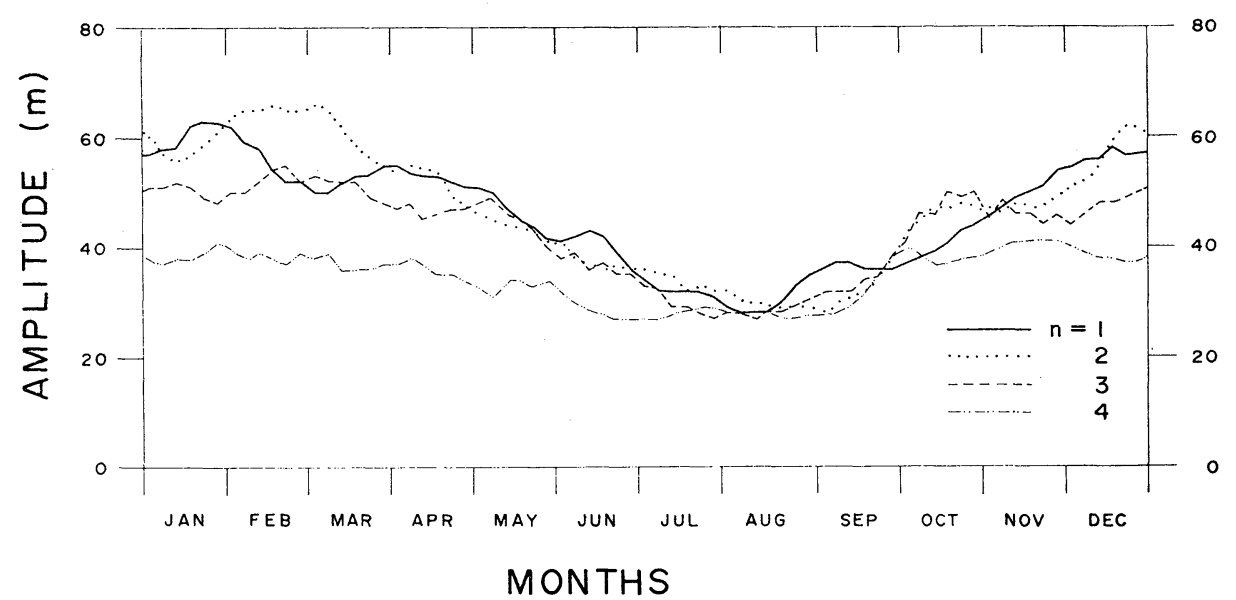

Fig. 7. Seasonal variation of the normal amplitude for the first four harmonics at $60^{\circ} \mathrm{N}$. Full line: the first, dotted line: the second, broken line: the third and dotted broken line: the fourth harmonic.

7 shows that the amplitudes of the first three harmonics are large in winter and small in summer. The variation for the fourth harmonic is generally small throughout the year. The amplitudes of the first four harmonics become the same order of magnitude, about $30 \mathrm{~m}$, in August.

The frequency distributions of phase velocities in four seasons are given in Fig. 8 for the first harmonic at $70^{\circ} \mathrm{N}$ (upper figure) and for the second harmonic at $60^{\circ} \mathrm{N}$ (lower figure). Generally speaking, the mean westward phase veloctites are not different from season to season and no

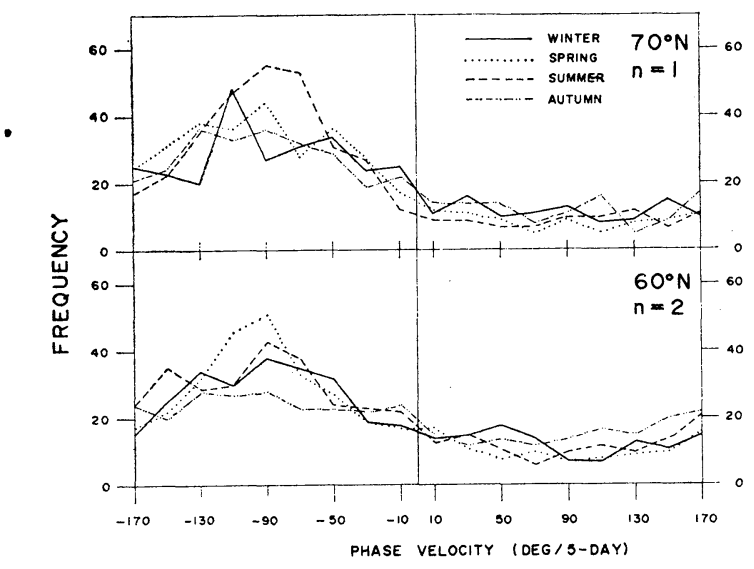

Fig. 8. Frequency distributions of phase velocities for transient waves for the first (upper) and the second (lower) harmonic. Full line: winter, dotted line: spring, broken line: summer and dotted broken line: autumn. seasonal variation can be detected, because the distributions are not so sharp. However, the mean westward phase velocity of the first harmonic seems to be smaller in summer than in the other seasons. The distribution for the second harmonic in autumn at $60^{\circ} \mathrm{N}$ is considerably flat showing that no mean westward motion is to be found in this season.

\section{Examples of travelling waves}

Four examples of transient waves are presented in this section. Fig. 9 shows the phase angles and amplitudes of the transient waves for the first harmonic at $60^{\circ} \mathrm{N}$ from November 1952 to April 1953. The phase velocities ranging from $-30^{\circ}$ to $-150^{\circ} / 5$-day are defined as the westward movement and shown by full lines. The rest is given by broken lines. Continuous westward displacement is clearly seen during the period except for a few pentads. The amplitudes are large on the average and their variation is also very large. The westward movement has a tendency to be obscured when the amplitudes are small.

Fig. 10 shows the phase angles and amplitudes of the second harmonic at $60^{\circ} \mathrm{N}$ from November 1956 to April 1957. The westward movement is pronounced after January 1957. Fig. 11 is the variation of the third harmonic at $60^{\circ} \mathrm{N}$ from November 1967 to April 1968. The eastward movement is defined by phase velocities ranging from $30^{\circ}$ to $150^{\circ} / 5$-day and given by broken lines. The phase velocities ranging from $30^{\circ}$ to $-30^{\circ} / 5$-day and from $-150^{\circ}$ to $150^{\circ} / 5$-day are 
shown by dotted lines. We can see that the westward and eastward movements occur alternately. The amplitudes are generally large in January, February and March 1968.

Finally, the 5-day mean $500-\mathrm{mb}$ heights at $60^{\circ} \mathrm{N}$,

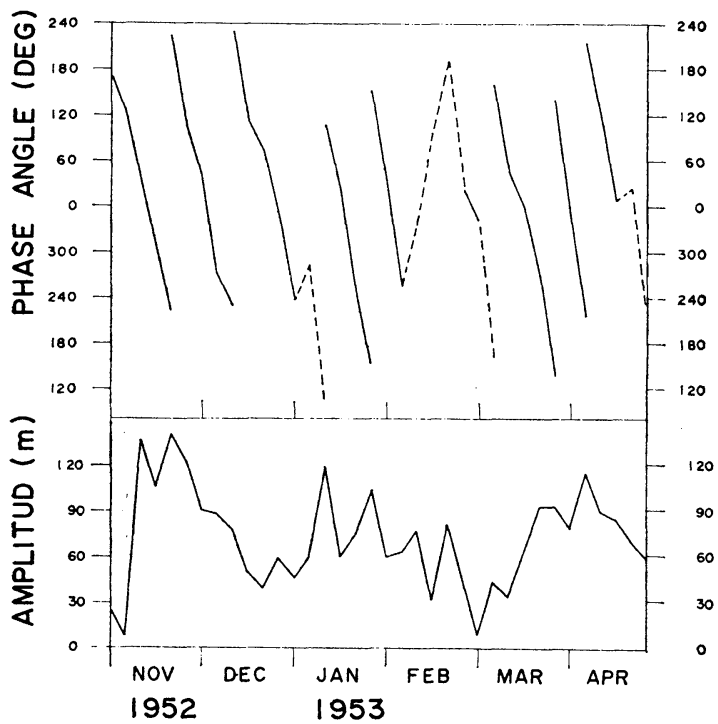

Fig. 9. Phase angles and amplitudes of transient waves for the first harmonic at $60^{\circ} \mathrm{N}$ from November 1952 to April 1953. The westward displacements, the phase velocities ranging from $-30^{\circ}$ to $-150 /$ 5-day, are shown by full lines and the rest by broken lines.

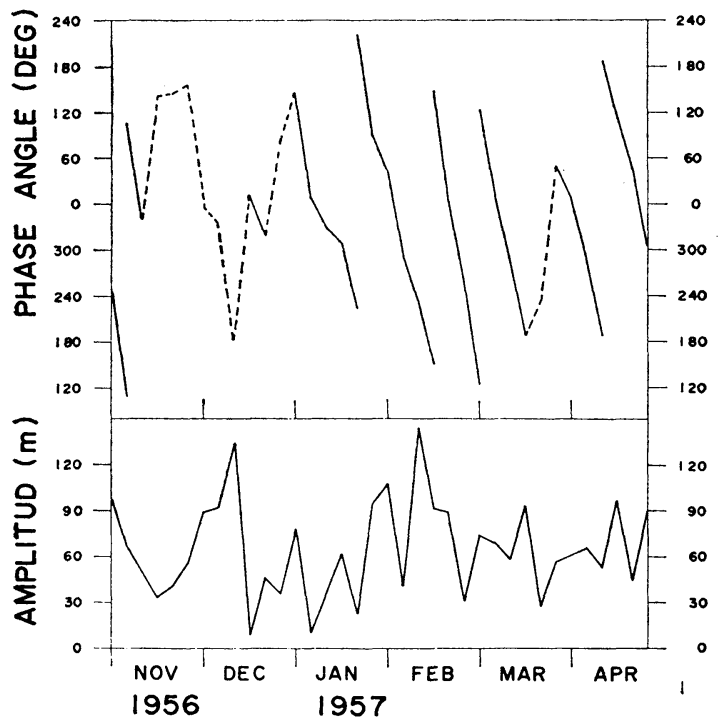

Fig. 10. The same as Fig. 9 but for the second harmonic from November 1956 to April 1957. departures from 25-day mean, are shown in Fig. 12 for each pentad from 5 Sepember to 10 October 1956, the date in the Fig. indicating the middle day for each pentad. The negative heights are shaded. The movement of ridges of the fourth harmonic is represented by heavy full lines and that of troughs by heavy broken lines. The

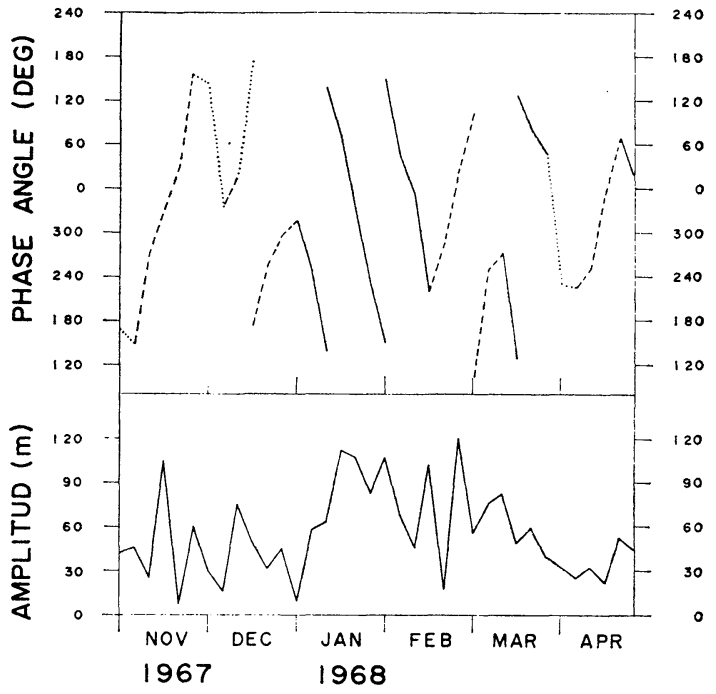

Fig. 11. The same as Fig. 9 but for the third harmonic from November 1967 to April 1968. Dotted lines show phase velocities with the range from $-30^{\circ}$ to $30^{\circ} / 5$-day and from $150^{\circ}$ to $-150^{\circ} \%$ 5-day.

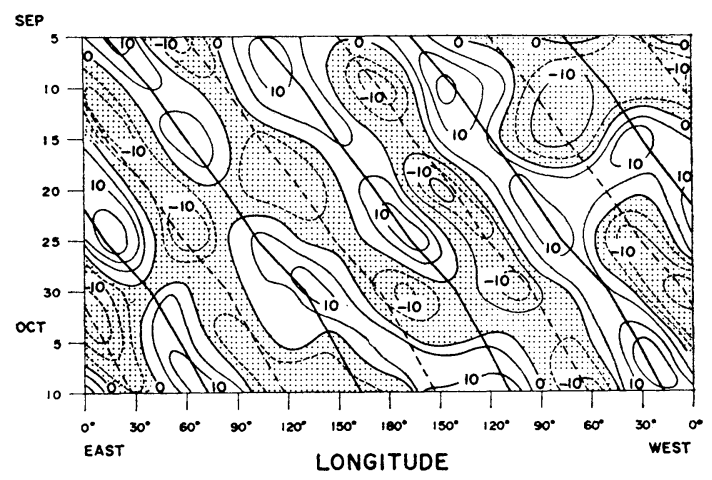

Fig. 12. Isopleths of 5-day mean 500-mb heights, departures from 25-day mean, at $60^{\circ} \mathrm{N}$ from 5 September to 10 October 1956. Negative heights are shaded. Heavy full lines indicate the eastward displacement of ridges and heavy broken lines that of troughs of transient waves for the fourth harmonic. 
amplitudes of the first and second harmonics are largely small in this case. The 5-day mean field move eastward at a mean rate of $4^{\circ}$ longitude/day coinciding with the movement of transient waves for the fourth harmonic except for a few discrepancies. There are many excellent examples as expected from the statistical evidence of traveling waves.

\section{Conclusion}

The results obtained above may be summarized as follows:

(1) The transient waves of the first and second harmonics move westward at $70^{\circ}$ and $60^{\circ} \mathrm{N}$ on the average, whereas the westward movement is not pronunced at lower latitudes mainly due to the smallness of amplitude.

(2) The mean westward phase velocity is about a quarter of the wave-length per 5 days. This is equal to the longitudinal speed of $-20^{\circ}$ and $-10^{\circ}$ longitude per day for the first and second harmonics respectively.

(3) The third harmonic does not reveal any mean westward or eastward movement at each latitude.

(4) The transient waves of the fourth harmonic move eastward at a mean rate of about $6^{\circ}$ longitude/day at $70^{\circ}$ and $60^{\circ} \mathrm{N}$, but they have a tendency to move westward at lower latitudes in summer.

(6) The mean phase velocities of the transient waves for the first two harmonics at $70^{\circ}$ and $60^{\circ} \mathrm{N}$ are nearly the same for each season, and the normal amplitudes of the first three harmonics are large in winter and small in summer. The seasonal variation of the amplitudes for the fourth harmonic is not large.

There are many spectral studies of harmonic waves in the troposphere and stratosphere. Saltzman and Teweles (1964) stated that the second harmonics were sources of kinetic energy. Using the correlation of daily spectral statistics for the stratosphere and troposphere, Teweles (1963) showed a number of significant interlevel relationships in the growth and decay of the longer cyclone waves. At the same time, the dynamics of planetary waves have been investigated by many authors. On the basis of linearized purturbation equations, Hirota (1968) made a theoretical study and discussed the vertical structure and phase velocity of the waves obtained.

There are also many analyses available about the movement of long and ultralong waves. Based on spherical harmonic analyses, Deland (1965) and Eliasen and Machenhauer (1965) showed that the largest components move generally westward and the westward speeds are nearly the same as those corresponding to the non-divergent vorticity equation or the Rossly-Haurwitz wave speed. The mean westward speeds obtained in the present study are about one third of those given by Deland and Eliasen. This may be due to the fact that the travelling waves whose period is about 5 days as presented by Eliasen are mostly eliminated from the 5 -day mean 500 -mb charts.

The zonal harmonic analyses were utilized by Kubota and Iida (1954) to study the behavior of planetary waves on the $500-\mathrm{mb}$ level. The mean speeds during the 36 -day period are $-22^{\circ},-13^{\circ}$ and zero longitude per day for the first, second and third harmonics respectively. These values agree well with the mean phase velocities obtained in the present study. Daily 500 -mb heights and departures from the mean for the 36-day period, which were employed by Kubota and Iida, have certain similarities to the present author's method.

There is no physical background to the waves defined in this study and the mechanism of transient waves is not yet known. The transient waves are, however, closely connected with blocking waves. This will be discussed in detail in near future.

\section{Acknowledgments}

The author wishes to express his sincere thanks to Prof. R. Yamamoto, Kyoto University, and Dr. M. Magata, Meteorological Research Institute, for their valuable suggestions and encouragements throughout the present study. The author wishes to extend his thanks also to the staff members of the Forecast Research Laboratory of the Meteorological Research Institute for their helpful discussions. Thanks are also due to Mr. E. Yajima and Mrs. K. Honda for their assistance.

\section{References}

Anderssen, E. C., 1965: A study of atmospheric long waves in the southern hemisphere. Notos, 14, 57-65.

Arai, Y., 1965: A statistical study of planetary waves. J. Meteor. Soc., Japan, 43, 42-51.

, 1970: Seasonal variation of planetary waves. Papers Meteor. Geophys. (to be published)

Deland, R. J., 1964: Travalling planetary waves. Tellus, 16, 271-273. 
Deland, R. J., 1965: Some observations of the behavior of spherical harmonic waves. Mon. Wea. Rev., 93, 307-312.

and K. W. Johnson, 1968: A statistical study of the vertical structure of travelling planetary-scale waves. Mon. Wea. Rev., 96, 12-22.

Eliasen, E., 1958: A study of the long atmospheric waves on the basis of zonal harmonic analysis. Tellus, 10, 206-215.

and B. Machenhauer, 1965: A study of the fluctuations of the atmospheric planetary flow patterns represented by spherical harmonics. Tellus, 17, 220-238.

Haney, R. L., 1961: Behavior of the principal harmonics of selected 5-day mean $500-\mathrm{mb}$ charts. Mon. Wea. Rev., 89, 391-396.
Hirota, I., 1968: On the dynamics of long and ultra long waves in a baroclinic zonal current. J. Meteor. Soc., Japan, 46, 234-249.

, 1968: Planetary waves in the upper stratosphere in early 1966. J. Meteor. Soc., Japan, 46, 418-430.

Kubota, S. and M. Iida, 1954: Statistical characteristics of the atmospheric disturbances. Papers in Meteor. Geophys., 5, 22-34.

Saltzman, B. and S. Teweles, 1964: Further statistics on the exchange of kinetic energy between harmonic components of the atmospheric flow. Tellus, 16, 432-435.

Teweles, S., 1963: A spectral study of the warming epoch of January-February 1958. Mon. Wea. Rev., 91, 505-519.

\title{
超 長 波 の 統 計 的 研 究
}

\author{
荒井康 \\ 気象研究所
}

20 数年間の半旬平均 $500-\mathrm{mb}$ 高度, 25 日平均高度, 両者の差(トランジェント), 偏差, 時間差の各高度場を, $70^{\circ} \mathrm{N}$ から $30^{\circ} \mathrm{N}$ までの各緯度毎に調和分析し, 波数 1 から 4 までの超長波の統計的特性を解析した. その結果, $70^{\circ} \mathrm{N}$ と $60^{\circ} \mathrm{N}$ の波数 1 と 2 のトランジェント波が，平均的に西進する事実を見出した。この西進の割合は全例の 70 80\%で その平均の西向きの位相速度は 5 日間に約 4 分の 1 波長である。すなわち波数 1 のトランジェント波は 1 日に経度約 $20^{\circ}$ ，波数 2 は約 $10^{\circ}$ で平均的に西進する。この事実は低緯度では顕著でないが，これは主として振巾の小さいため である.

これに反して波数 3 のトランジェント波は, 西進拉よび東進の割合はほぼ同じで, どちらかにより多く移動すると いらことはない．また $70^{\circ} \mathrm{N}$ と $60^{\circ} \mathrm{N}$ の波数 4 のトランジェント波は平均的に東進し，その平均位相速度は 1 日に経 度約 $6^{\circ}$ である．低緯度の波数 4 の波は夏期には西進する傾向がある.

波数 1 ない 3 のトランジェント波の振巾は, 一般に冬に大きく夏に小さいが, 波数 4 の波の振巾は顕著な季節変 化を示さない。また波数 $1 ， 2$ のトランジェント波の位相速度には，四季の差がはっきりとは認められない。 